\title{
Honey-bee production practices and hive technology preferences in Jimma and Illubabor Zone of Oromiya Regional State, Ethiopia
}

\author{
Welay KIROS, Tekleberhan TSEGAY \\ School of Animal and Range Sciences, \\ Haramaya University, Ethiopia \\ P.O. BOX: 138, Dire-dawa, Ethiopia \\ e-mail: kirosw47@gmail.com
}

Manuscript received March 11, 2017; revised March 30, 2017; accepted April 5, 2017

\begin{abstract}
The study was conducted in two purposefully selected zones of Oromiya Regional State, namely Jimma and Illubabor. The objective of the study was to analyse the honey-bee production and to assess hive technology preferences in the study area. A total of 156 beekeepers were randomly and proportionately selected from four districts (Mana and Gomma from Jimma and Bacho and Yayo from Illubabor). Data were collected through formal survey and secondary sources. Accordingly, the average age of the beekeepers was $40.2 \pm 8.13$ years with an average of $13.5 \pm 6.58$ years of experience. The majority of the respondents $(53.2 \%)$ in the study area got their colonies by catching swarms. Three hive types (traditional, transitional, and frame hive) were found in the study area. More than $70 \%$ of the respondents harvested once a year from traditional hives, while $25 \%$ of respondents harvested up to three times per year from frame hives. Moreover, an average of $22 \pm 4.6$ and $16 \pm 4.1 \mathrm{~kg}$ of honey were harvested from frame and transitional hives per year, respectively. Compared to these two hives, a much lower $(7 \pm 1.6 \mathrm{~kg})$ amount of honey was harvested from traditional hives. Various honey-bee floras were identified in the study area. Plants such as Vernonia amygdalina, Croton macrostachyus, and Schefflera sp. produce white honey. Half of the respondents' preferred transitional hive followed by frame hive $(37.2 \%)$. Factors which affect the use of frame hives were lack of equipment $(36.5 \%)$ followed by wax quality and availability problems (34\%). That is why few beekeepers tried to modify the frame hive to solve the problems of wax in vertical frame hive. In order to adopt and sustain modern hive technology, the focus should be on honey-bee equipment as well as wax quality and availability.
\end{abstract}

Keywords: beekeeping, honey production, hive preference 


\section{Introduction}

Ethiopia has huge potential for beekeeping production because of its endowment with diversity in climate and vegetation resources offering potentially favourable conditions for beekeeping. These have enabled Ethiopia to take around $23.58 \%$ and $2.13 \%$ of the total share of honey production on African and on a global level respectively [21].

The exact number of people engaged in the honey subsector in Ethiopia is not known. However, it is estimated that more than one million farm households are involved in the beekeeping business using the traditional, intermediate, and frame beehives [13]. It could also be observed that a large number of people (intermediaries and traders) participate in honey collection and retailing (at village, district, and zonal levels), and thousands of households are engaged in tej making in almost all urban areas, while also hundreds of processors are emerging, and exporters are flourishing [3].

Generally, about 4,601,806 beehives exist in Ethiopia, out of which about 95.5\% are traditional, $4.3 \%$ transitional, and $0.2 \%$ frame beehives [3]. Based on the national estimate, the average yield of pure honey from movable frame beehive is $15-20 \mathrm{~kg} / \mathrm{year}$, and the amount of beeswax produced is $1-2 \%$ of the honey yield [12]. However, in potential areas, up to $50-60 \mathrm{~kg}$ of harvest has been reported [14].

Despite the high potentiality of the country for beekeeping and its extensive practices, beekeeping research conducted in the nation so far has not managed to characterize and document the apicultural resources and associated constraints of the sector for its proper intervention and utilization to specific potential regions [4]. Success in beekeeping primarily results from the utilization of improved beekeeping technologies that are suitable for local bee types and conditions [15]. These conditions may generally indicate the importance of considering the biology and ecology of the bees in the selection and adoption of technologies. Besides the technological and biological factors, the socio-demographic conditions of beekeepers were observed to play a significant role in the adoption of technologies. Thus, it was essential to assess the beekeeping production system as a whole and identify the determinants of hive technology preference and the major constraints of this subsector.

According to the Central Statistics Agency (2011/12), Oromia has the largest number of beehives followed by Amhara and SNNP. Jimma, Illubabor, and West Wellega were the areas of Oromia region with the highest number of hives (CSA, 2011/12) [5]. Different case studies and researches are being carried out concerning honey-bee production practices and honey-bee diseases and pests in different areas of the country. However, there is no compiled and tangible information on the 
preference of hive technology and management as well as constraints in the potential honey-bee areas (Illubabor and Jimma). Therefore, this research has been initiated with the objective of assessing honey-bee production and identifying the preference of hive technology in the Illubabor and Jimma zones.

\section{Materials and methods}

The study was conducted in the two neighbouring zones of Jimma and Illubabor, which are found in the south-western part of Ethiopia, having the highest number of hives (CSA, 2011/12) in the Oromia region. According to the zonal offices of Illubabor and Jimma (information from 2014), honey production is one of the most important sources of local earnings. Besides that, Jimma and Illubabor zones share many similarities in their agro-ecological conditions, cropping systems, vegetation types, and climatic conditions. In both zones, the dominant crops are maize, teff, coffee, sorghum, barley, wheat, different pulse crops, finger millet, fruits, vegetables, and spices. Annual precipitation ranges from 1,500 to 2,200 mm with 6 to 9 months of rainfall $[5,16]$.

Jimma and Illubabor zones have been selected purposefully because of their apiary potentials. A total of four districts (Mana and Gomma from Jimma and Bacho and Yayo from Illubabor) were selected based on the criteria of having large number of participants in beekeeping, beekeeper experience, potential area for beekeeping, abundance of honey-bee colonies, and availability of common bee forage. These were identified with the help of zonal agricultural and rural development offices and agents of the respective districts. A total of 156 beekeepers were randomly selected and interviewed proportionately from the districts. The sample size $(\mathrm{N})$ was determined using the formula recommended by Arsham (2005) as $\mathrm{N}=0.25 / \mathrm{SE} 2$, where $\mathrm{N}$ is sample size, and $\mathrm{SE}$ is the standard error at $4 \%$. However, data was pooled and analysed into one zone because of the similarity of results across the districts.

Data were collected from September 2014 to June 2015 through formal survey, secondary sources, focus-group discussions, key-informant interviews, and field observations. Relevant information was further collected through discussions with representatives of the district and zonal office of Agricultural and Rural Development and Development Agents. Formal survey was conducted using semistructured questionnaire with open-ended and closed-ended questions. The questionnaire was prepared to collect information as: age of the respondent, hive preference, beekeeping and/or management practices, placement of hives, honeybee inspection, major bee floras, honey yield, and major constraints for adopting improved hives. 
The collected data were analysed using appropriate statistical packages for social sciences (SPSS - software version 20). Descriptive statistics, such as mean, frequency, and standard deviation, were used.

\section{Results and discussions}

The study revealed that the average age of the beekeepers was $40.24 \pm 8.13$ years, with a range of 25-60 years. This result correlates with Chala et al. (2013) and Gebremedhin (2015), who report that the mean age of the respondents were 40.47 and 40.1 years respectively $[4,11]$. The age distribution of beekeepers is generally within the active working age. Regarding their experience in beekeeping, the respondents had an average of $13.51 \pm 6.58$ years of experience, with a range of 5-28 years of working practice with honey-bees. This indicates that beekeepers have a good knowledge of apiary management and honey usage habits.

The majority of the respondents $(53.2 \%)$ in the study area got their colonies by catching swarms or as a present from their parents (42.9\%). This is in line with Addis and Malede (2014), who reported that $49.2 \%$ of the beekeepers started out by catching swarms. (This might be due to the fact that the area is endowed with species of plants that are favoured by bees.) Very few beekeepers $(6.4 \%)$ were supplied by the government or NGOs. It was possible to buy a colony in the study area, even though only $17.3 \%$ of the respondents availed themselves of this opportunity (Table 1).

Table 1. Source of bee colonies

\begin{tabular}{lcc}
\hline \multicolumn{1}{c}{ Sources } & Number of respondents & Percentage \\
\hline Catching swarms & 83 & 53.2 \\
Gift from parents & 57 & 36.5 \\
Given by Government or NGO & 10 & 6.4 \\
Buying & 27 & 17.3 \\
\hline
\end{tabular}

It can be clearly seen in Table 2 that half of the respondents preferred transitional hives. However, the average honey-bee colony holding size (10.7 \pm 4.3$)$ for traditional was a little bit bigger than two hives. Contrary to the results of this study, Nebiyu and Messele (2013) found that $74.4 \%$ of the beekeepers in the Gamo Gofa zone, southern Ethiopia, preferred traditional hives over transitional (11.5\%) and modern hives (14.1\%) [18]. This might be related to an availability of local materials with the experience and knowledge gap of beekeepers for the preference of hive technologies in different areas of the country. Frame hive was preferred by 
$37.2 \%$ of the respondents next to transitional hive with the least average of colony holding size $(6.08 \pm 5.01)$. During group discussions with key informants and zonal offices of the study area, those having an experience in apiary preferred transitional hives for purposes of wax production. In addition, very few beekeepers tried to modify the frame hive - as shown in Picture 1 -, giving evidence of a better management and obtaining higher earnings. This is consistent with Tessega's (2009) findings, who noted that experienced and skilful beekeepers could do many operations with less facilities [20].

Table 2. Respondents' hive preference and honey-bee colony holding size

\begin{tabular}{lccc}
\hline Hive type & $\begin{array}{c}\text { Number of } \\
\text { respondents }\end{array}$ & Percentage & $\begin{array}{c}\text { Colony holding size in } \\
\text { different hives (Mean } \pm \text { SD) }\end{array}$ \\
\hline Traditional & 20 & 12.8 & $10.7 \pm 4.3$ \\
Transitional & 78 & 50 & $9.51 \pm 9.9$ \\
Frame hive & 58 & 37.2 & $6.08 \pm 5.01$ \\
Total & 156 & 100 & \\
\hline
\end{tabular}
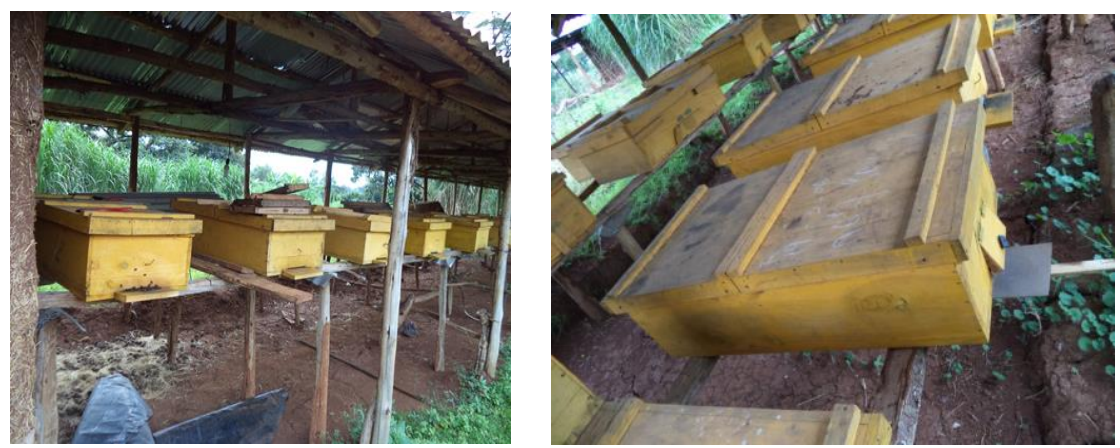

Picture 1. Horizontal frame hive with two and three compartments modified by a beekeeper in Bacho district

As shown in Table 3, an average of $22 \pm 4.56$ kilogram of honey per year from frame hives and $16.2 \pm 4.12$ kilogram of honey from transitional hives were harvested. Compared to these two types, a much lower $(6.97 \pm 1.58)$ amount of honey was harvested from traditional hives. The present result was in agreement with the result reported by Addis and Malede (2014) and Chala et al. (2013), who found that the average honey yield per year/colony was $7.20 \pm 0.23,14.70 \pm 0.62$, and $23.38 \pm 0.73 \mathrm{~kg}$ for traditional, transitional, and moveable frame hives respectively [4]. However, the mean honey yield obtained from transitional hives in this study area is higher than the result indicated by Nebiyu and Messele (2013) in the districts of Gamo Gofa zone, southern Ethiopia, which is $14.07 \mathrm{~kg}$ per hive/year [18]. The productivity of frame hive and transitional in this study is more than triple than that 
of traditional hives, which is perhaps because of better management practices such as providing wax foundation sheets, recycling drawn-out combs after honey extraction, and a higher frequency of harvesting. A better honey storing of colonies in box hives with foundation sheet has been reported by [2]. Moreover, the possible advantages of increasing the overall average honey yield of colonies in box hives as compared to traditional hives has been well documented in Nigeria [9]. In this regard, to improve the output of beekeeping, the adoption of improved hives is important.

Table 3. Honey production ( $\mathrm{kg} / \mathrm{hive} / \mathrm{year}$ ) from three types of hives

\begin{tabular}{lccc}
\hline \multicolumn{1}{c}{ Types of hive } & $\begin{array}{c}\text { Minimum } \\
\text { (kg/hive/year) }\end{array}$ & $\begin{array}{c}\text { Maximum } \\
\text { (kg/hive/year) }\end{array}$ & Mean \pm SD \\
\hline Traditional hive & 4 & 8 & $6.97 \pm 1.58$ \\
Transitional hive & 7 & 21 & $16.2 \pm 4.12$ \\
Frame hive & 12 & 32 & $22 \pm 4.56$ \\
\hline
\end{tabular}

$\mathrm{SD}=$ Standard deviation

As shown in Figure 1, more than $70 \%$ of the respondents harvested honey once a year from traditional hive. In addition, respondents having transitional (33\%) and frame hive (22\%) also harvest honey once a year, even though the hive technology is improved. About 53\% of the respondents having frame hive were able to harvest twice a year, which is slightly higher than noted for transitional hive $(48 \%)$ and much higher than the traditional hive (27\%).

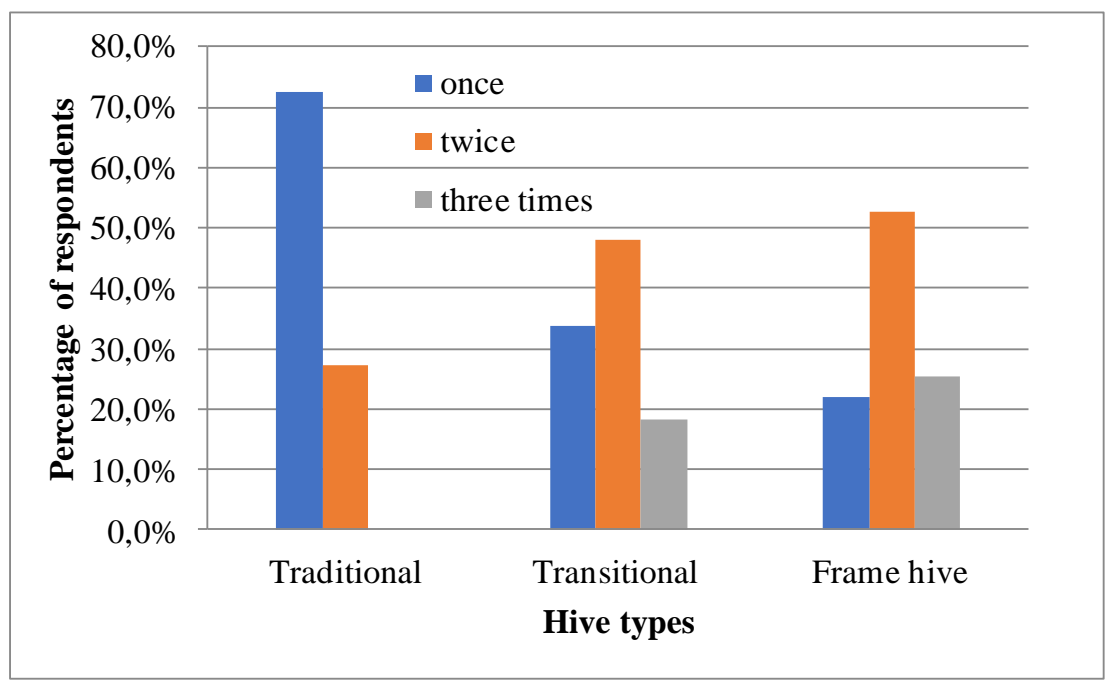

Figure 1. Honey-harvesting frequency for three hives 
Moreover, $25 \%$ of the respondents' harvested honey three times a year in frame hives, while only $18 \%$ of respondents did it in transitional hive, and nobody experienced three times of harvesting a year in traditional hive. This research result was in line with Tessega (2009), who reported honey harvested once or twice, and in some cases even three times in Burie district [20]. This clearly indicates that harvesting frequencies differ within the same area but with different hive technologies. On the other hand, having three times of honey harvesting per year is an indication of the area being convenient for apiculture development.

More than $87 \%$ of the sample respondents who owned transitional and frame hive kept their colonies around their homestead (back yard) mainly to enable close supervision of colonies, whereas some of the respondents (12.5\% and 6.6\%) kept transitional and frame hive, respectively, hanging near their homestead. Besides, $58.9 \%$ of traditional bee colonies were kept in forests so that they might attract wild swarms. As mentioned during group discussions, when honey is harvested from traditional hive, absconding happens sometimes, and the hive has to return back, for which they use smoke to attract bees. Only $11 \%$ of respondents kept their traditional hive colony in the backyard, which is easier for harvesting as well as inspection than hanging nearby in the forests (Table 4). In some places, especially in the western and southern parts of the country, forest beekeeping by hanging a number of traditional beehives on trees is widely practised. In most other parts of the country, backyard beekeeping with relatively better management is common [19].

Table 4. Traditional, transitional, and frame hive placements

\begin{tabular}{lccccccc}
\hline Hive type & $\begin{array}{c}\text { Back } \\
\text { yard }(\mathbf{N})\end{array}$ & $\%$ & $\begin{array}{c}\text { Hanging near } \\
\text { home stead }\end{array}$ & $\%$ & $\begin{array}{c}\text { Hanging near } \\
\text { in the forest }\end{array}$ & $\%$ & Total \\
\hline Traditional & 8 & 11.0 & 22 & 30.1 & 43 & 58.9 & 73 \\
Transitional & 91 & 87.5 & 13 & 12.5 & 0 & 0 & 104 \\
Frame hive & 85 & 93.4 & 6 & 6.6 & 0 & 0 & 91 \\
\hline
\end{tabular}

Regular assessments and rapid detection of honeybee pests at their respective areas has paramount importance to prevent the loss of honey product due to pest attack [7]. However, in this study, both internal and external inspections were done sometimes by $48 \%$ and $46 \%$ of the respondents respectively. Unlike the external inspection, internal inspection was frequently done by about $29 \%$ of the respondents. Approximately $18 \%$ the respondents rarely inspect their hives internally. Below 5\% of the respondents never inspect their hives, except visiting for harvesting. 


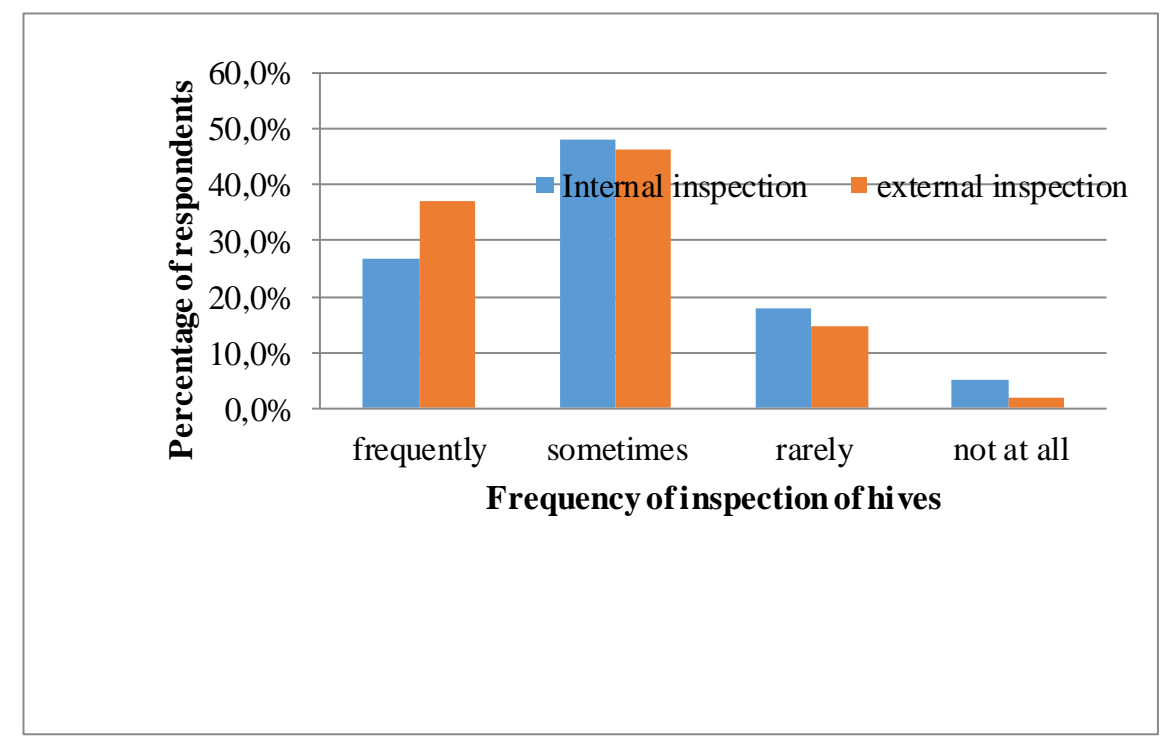

Figure 2. Internal and external honey bee inspections

According to the respondents, various honeybee plants exist in the area. In addition, respondents mentioned that different plants were responsible for the different colours of honey. Accordingly, plants like Vernonia amygdalina, Croton macrostachys, and Schefflera abyssinica produce white honey, while Syzgium guineense and Bidens pachyloma produce red honey. Similar plant species were identified as major pollen and nectar sources, for honeybees in Manasibu districts (Mathewos et al., 2004) and around the central low-land area (Amssalu 2000). Farmers reported that Guizotia scabra was a dominant honeybee forage in both Shashemene and Arsi Negelle districts, followed by croton macrostachys. Similarly, they argued that one of the critical factors that drive apiculture development is the availability of adequate quantities and the quality of bee forages.

About $72 \%$ of the respondents gave supplementary feed during the dry season, while $28 \%$ of the sampled beekeepers did not supplement. This might be due to lack of money to buy the supplementary feeds or may be due to lack of knowledge. Common feeds used as supplements during dry season were sugar, berbre, honey, shiro, maize powder, and chopped sugar cane.

Respondents gave varied reasons why they did not prefer frame hive technology (Table 6). Accordingly, lack of equipment was the first factor noted by $36.5 \%$ of the respondents, followed by wax quality and availability problem (34\%). 
Table 5. Honeybee forages reported by the respondents in the study area

\begin{tabular}{clcc}
\hline No & \multicolumn{1}{c}{ Scientific names } & Local name & Plant type \\
\hline 1 & Vernonia amygdalina & Ebicha & Shrub \\
2 & Syzgium guineense & Badessa & Tree \\
3 & Eucalyptus spp & Bargemo & Tree \\
4 & Apodytes dimidiate & Oda beda & Tree \\
5 & Acacia sibirana & Lafto & Tree \\
6 & Prunus Africana & Miessa & Tree \\
7 & Schefflera abyssinica & Gatame & Tree \\
8 & Croton macrostachys & Mokonissa & Tree \\
9 & Guizotia scabra & Adala & Herb \\
10 & Cordia Africana & Wodesa & Tree \\
11 & Schinus molle & Turimanturi & Tree \\
12 & Agave sisalana & Kancha & Shrub \\
13 & Allium cepa & Shunkurti dima & Crop \\
14 & Vernonia amygadalina & Girawa & Shrub \\
15 & Gizotia scabira & Hadaa & Shrub/herb \\
16 & Bidens pachyloma & Kelo & Herb \\
\hline
\end{tabular}

Discussants mentioned that affordability, availability, quality of materials especially of the hives -, the inferior quality of wax, and lack of accessories were the major factors that hampered to use modern hives in the study area. That's why a few beekeepers tried to modify the frame hive to solve the problem of wax in vertical frame hive, and these hives were made of quality timber, offering better conditions for opening and managing them more easily. Some related problems were identified, such as the lack of skill in modern bee management, which had contributed to colony absconding and low honey production [4].

Table 6. Factors which affect usage of frame hives as reported by respondents

\begin{tabular}{lcc}
\hline \multicolumn{1}{c}{ Factors } & Number of respondents & \% \\
\hline Lack of awareness & 46 & $29.5 \%$ \\
Skill personnel & 24 & $15.4 \%$ \\
Lack of equipment & 57 & $36.5 \%$ \\
Durability of hive & 45 & $28.8 \%$ \\
Wax quality and availability problem & 53 & $34.0 \%$ \\
\hline
\end{tabular}

Respondents listed pests and predators which affect honey bee like ant, wax moth, birds, spiders, and lizards. According to the response of beekeepers, ant 
$(65.5 \%)$ attack was a serious problem in the study area, followed by wax moth (52.4\%). Frequent cleaning of the apiaries, using ash, and killing of the predators were remedies done by some of the respondents. Bee lice were the least problem, mentioned by $6.3 \%$ of the respondents. Similarly, Adeday et al. (2012) in Wukro Tigray region noted similar pests and predators [1]. Moreover, according to the result obtained by Debassa and Belay (2015), in Walmara district, $75.4 \%$ of the sample respondents lost up to five colonies due to pests and predators [6].

Table 7. Major pests and predators reported by respondents

\begin{tabular}{lc}
\hline \multicolumn{1}{c}{ Factors } & Beekeepers who consider pests and predators are important $(\%)$ \\
\hline Ant & $65.5 \%$ \\
Wax moth & $52.4 \%$ \\
Birds & $47.3 \%$ \\
Spiders & $26.5 \%$ \\
lizards & $7.8 \%$ \\
Bee lice & $6.3 \%$ \\
\hline
\end{tabular}

Among the sampled beekeepers in Table 8, only $55.8 \%$ had received some training in bee management for two and three days at Farmers Training Center (FTC), near the town and regional city. Of those who had been trained, 58.2\% took their training at the nearby town, followed by FTC (26.9\%), while the minority $(14.9 \%)$ were instructed in a regional city with the help of governmental and nongovernmental organizations. These results suggest that acquisition of technical skills and knowledge of bee farming were likely to influence the adoption of modern beekeeping technology.

Table 8. Respondents' experience on training of bee management

\begin{tabular}{lcc}
\hline \multicolumn{1}{c}{ Training experience } & Number of respondents & Percentage \\
\hline Respondents took training & 67 & 55.8 \\
Respondents did not take training & 89 & 44.2 \\
Total & $\mathbf{1 5 6}$ & $\mathbf{1 0 0}$ \\
Place of traning & & \\
At FTC & 18 & 26.9 \\
In a nearby town & 39 & 58.2 \\
In a regional city & 10 & 14.9 \\
Total & $\mathbf{6 7}$ & $\mathbf{1 0 0}$ \\
\hline
\end{tabular}

FTC $=$ Farmer Training Centre 


\section{Conclusion}

The productivity of frame and transitional hives is, more than triple than that of traditional hives. This is perhaps because of better management practices, such as providing wax foundation sheets, recycling of drawn out combs after honey extraction, and higher frequency of harvesting. Honey harvesting is done once, twice, or three times a year, and a variation among hive types can be clearly seen in the frequency of honey harvesting. Honey harvesting from frame hives and transitional hives takes place more than twice a year.

Half of the respondents preferred transitional hive, even though the average honey bee colony holding size for traditional was a little bit higher than the two hives. Major factors affecting choice of frame hive technology: lack of equipment, and wax quality and availability problems were mentioned as a first and second factors which affect the adoption of frame hive technology. In addition, pests and predators such as ants and wax moth were problems for honey bee colony in the study area.

Various honey-bee floras, such as Vernonia amygdalina, Croton macrostachyus, Schefflera abyssinica, Syzgium guineense, and Bidens pachyloma, were identified, which plants are responsible for the different colours of honey. The majority of beekeepers have knowledge in colony feed supplementation during dry season, which has to be adopted by other beekeepers to sustain the colonies. More than half of the beekeepers took training in the study area for two to three days. This suggests that acquisition of technical skills and knowledge of bee farming were likely to contribute positively to farmers' adoption decision. In conclusion, in order to adopt and sustain the modern hive technology, the focus should be on honey bee equipment, hive and wax quality and availability.

\section{Acknowledgements}

We are highly grateful to the Ethiopian Institute of Agricultural Research (EIAR) for sponsoring of this project. We extend our gratitude to regional, zonal and district agricultural office workers for their cooperation and assistance during the study. We would also like to thank the beekeepers of the study area, who shared their knowledge and invaluable cooperation throughout the study period. 


\section{References}

[1] Adeday, G., Shiferaw, M., Abebe, F. (2012), Prevalence of bee lice Braula coeca (Diptera: Braulidae) and other perceived constraints to honey bee production in Wukro Woreda, Tigray Region, Ethiopia. Global Veterinaria 8(6), 631-635.

[2] Al-Ghamdi, A. A. (2007), Saudi beekeeping industry. $5^{\text {th }}$ International Arab Apicultural Conference Tripoli 25-28/11/2007.

[3] Beyene, T., David P. (2007), Ensuring small-scale producers in Ethiopia to achieve sustainable and fair access to honey markets. Paper prepared for international development enterprises (IDE) and Ethiopian society for appropriate technology (ESAT), Addis Ababa, Ethiopia.

[4] Chala, K., Taye, T., Kebede, D., Tadele, T. (2012), Opportunities and challenges of honey production in Gomma District of Ethiopia. International Conference on Bridge Scales and Epistemologies 1, Alexandria.

[5] CSA (2012), Agricultural sample survey 2011/2012 on livestock and livestock characteristics. Central Statistics Authority. Addis Ababa, Ethiopia.

[6] Dabessa, J., Belay, A. (2015), Survey on major honey bee pests and predators in Oromia special zone surrounding Finfine in Walmara District. European Journal of Biological Sciences 7(2), 62-70.

[7] Desalegni, B., Amsalu, B. (2012), Apiculture research achievements in Ethiopia, Oromia Agricultural Research Institute, Holeta Bee Research Center.

[8] Dixon, A. B. (2005), Wetland sustainability and the evolution of indigenous knowledge in Ethiopia. The Geographical Journal 171(4), 306-323.

[9] Fadare, S. O., Ojo, S. O., Imoudu P. B. (2008), Analysis of production performance of beekeeping in the Niger Delta Area of Nigeria. Apiacta 43, 37-48.

[10] Gebiso, T. (2015), Adoption of modern bee hive in Arsi Zone of Oromia Region: determinants and financial benefits. Agricultural Sciences 6, 382-396.

[11] Gebremedhn, B. (2015), Honeybee production systems in Kewet District of Amhara, Ethiopia. Livestock Research for Rural Development 27(5), 2015.

[12] Gezahegne, T. (2001), Beekeeping (in Amaharic). Mega Printer Enterprise, Addis Ababa, Ethiopia.

[13] Gidey, Y., Mekonen, T. (2010), Participatory technology and constraints assessment to improve the livelihood of beekeepers in Tigray Region, northern Ethiopia. Momona Ethiopia Journal of Science 2(1).

[14] HBRC (Holeta Bee Research Center) (1997), Beekeeping training manual (unpublished). HBRC, Holeta, Ethiopia.

[15] Hepburn, H. R., Radloff, S. E. (1998), Honeybees of Africa. Springer, Germany.

[16] LDMA (2010), Annual progress report. Livestock Development and Marketing Agency (LDMA). Ilu Aba Bora Zone Department of Agriculture. Mettu, Ethiopia.

[17] ORG (Oromia Regional Government) (2003), Gomma-District-based development program: project document. Oromia economic study project office. Addis Ababa, Ethiopia. 
[18] Nebiyu, Y., Messele T. (2013), Honeybee production in the three agro-ecological districts of Gamo Gofa zone of southern Ethiopia with emphasis on constraints and opportunities. Agriculture and Biology Journal of North America 4(5), 560-567.

[19] Nuru, A. (2002), Geographical races of the honeybees (Apis mellifera L.) of the northern regions of Ethiopia. $\mathrm{PhD}$ dissertation. Rhodes University, South Africa.

[20] Tessega, B. (2009), Honeybee production and marketing systems, constraints and opportunities in Burie District of Amhara Region, Ethiopia. A thesis submitted to the Department of Animal Science and Technology, School of Graduate Studies, Bahirdar University.

[21] Workneh, A., Puskur, R. (2011), Beekeeping sub sector challenges and constraints in Atsbi Wemberta District of Eastern Zone, Tigray Region, Ethiopia. Journal of Agriculture Extension and Rural Development 3(1), 8-12. 